\title{
THE ROLE OF LAW AND GOVERNANCE IN ADVANCING CLIMATE RESILIENCE AND CLIMATE JUSTICE
}

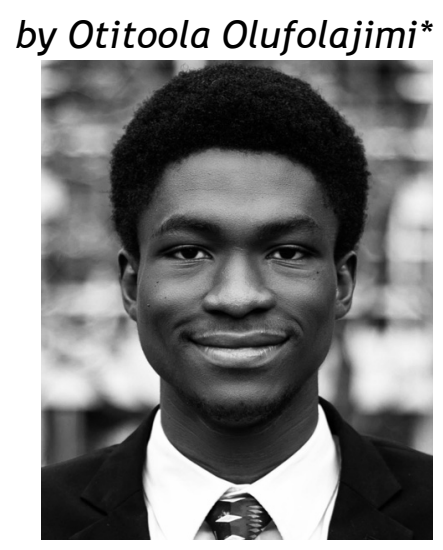

\section{Introduction}

'... but in this world nothing can be said to be certain, except death and taxes'. ${ }^{1}$ Climate change is a lot like death. We all understand that it is inevitable, but few of us truly accept it. Climate change is more than an environmental issue. Many of its consequences are social, economic and humanitarian. The past century has witnessed unprecedented human impacts on the natural environment. The United Nations listed 816 species that have become extinct and 11,046 species that are threatened with extinction. ${ }^{2}$ Nearly $25 \%$ of the world's most important marine fish stocks are depleted, overharvested or just beginning to recover from overheating. Another $44 \%$ are being fished at their biological limit and are therefore

* $\quad$ Fourth Year, LLB, University of Lagos, Nigeria. otitoolafolajimi@gmail.com.

1 B Franklin The private correspondence of Benjamin Franklin: comprising a series of letters on miscellaneous, literary, and political subjects: written between the years 1753 and 1790; Illustrating the memoirs of his public and private life, and developing the secret history of his political transactions and negotiations (1817) 1706.

2 United Nations Commission on Sustainable Development Global Status of Biological Diversity [E/CN,17/2001/PC/18] New York (2001). 
vulnerable to depletion. ${ }^{3}$ In 2006, 1 out of 5 people in the developing world did not have reasonable access to safe drinking water (as defined by the United Nations), and roughly 2 out of every 5 did not have basic sanitation. ${ }^{4}$ The global rate of deforestation averaged 9 million hectares per year in agricultural land worldwide and this has undoubtedly become a major issue. ${ }^{5}$ Issues such as species extinction, industrial pollution, forest loss, ecosystem degradation, overfishing and degraded freshwater supplies are all part of our contemporary world. $^{6}$

Climate change is a threat to the earth and sustainable development. There is no country in the world that is not experiencing first-hand, the drastic effects of climate change. ${ }^{7}$ Indeed, a large section of the global population already suffers or is in some way affected by the adverse effects of climate change, including its impacts on agriculture, aquaculture, livelihoods, biological diversity, health and a broad range of human rights. Although the impacts of climate change are felt globally, developing countries will bear the brunt of their social, economic and environmental effects. The populations living in the world's least developed countries are significantly more vulnerable to the consequences of a changing climate, while their 'carbon footprint' is negligible as compared to that of developed countries. Developing countries are more vulnerable to the impact and repurcussions of climate change because they have fewer resources needed to adapt. The 2011 UNDP Human Development Report and annual Intergovernmental Panel on Climate Change (IPCC) reports provide overwhelming evidence that we are reaching an upper limit of our capacity to emit greenhouse gases (GHGs) without dire consequences. ${ }^{8}$ Furthermore, global warming is causing long-lasting changes to our climate system, and these changes are sure to morph into irreversible consequences if we do not take immediate action. The annual average losses from earthquakes, tsunamis and flooding amount to hundreds of billions of dollars, requiring an investment of $\$ 6$ billion annually in disaster risk

3 United Nations World Resources Institute World Resources 2000-2001: People and ecosystems (2000) https://wriorg.s3.amazonaws.com/s3fs-public/pdf/world_ resources_2000-2001_people_and_ecosystems.pdf (accessed on 25 July 2018).

4 LR Brown \& L Starke State of the world 2004: A World Institute Report on progress toward a sustainable society (2004) at 7.

5 United Nations World Resources Institute Guide (n 3).

6 W Thomas 'Rio's unfinished business: American enterprise and the journey toward environmentally sustainable globalization' (2002) 32 Environmental Law Reporter at 10875.

7 United Nations on Sustainable Development Goals 'Goal 13: climate action' https://www.undp.org/content/undp/en/home/sustainable-development-goals/ goal-13-climate-action.html (accessed 2 August 2018).

8 United Nations on Development Programme 'Sustainability and equity: a better future for all' (2011) https://sustainabledevelopment.un.org/?menu=1300 (accesed 20 July 2018); Intergovernmental Panel on Climate Change 'Climate change: impacts, adaptation, and vulnerability' Working Group II, 5th Assessment Report (2014) https://www.ipcc.ch/report/ar5/wg2/ (accessed on 19 July 2018). 
management alone. ${ }^{9}$ One of the major aims of the United Nations Development Programme (UNDP) for Sustainable Development is to address the needs of developing countries and help mitigate climaterelated disasters; helping more vulnerable regions adapt to climate change through effective resilient approaches and climate justice. ${ }^{10}$

Climate resilience means the capacity for a socio-ecological system to adapt, reorganise, and evolve into more desirable configurations that improve the sustainability of the system, leaving it better prepared for future climate change impacts. ${ }^{11}$ Furthermore, climate resilience can refer to actions that either reduce climate impact or respond to climate impact. The concept of resilience has developed as communities, governments, and businesses gear up efforts to manage the unavoidable negative consequences of events tied to such trends. The degree to which a system - be it a society, a community, or the environment - can be resilient depends on its ability to be aware, diverse, self-regulating, integrated, and adaptive. Climate justice, on the other hand, is generally used as a term for viewing global warming as an ethical issue and considering how its causes and effects relate to concepts of justice, particularly environmental justice and social justice. This can mean examining issues such as equality, human rights, collective rights and the historical responsibility in relation to climate change. Equity and fairness are important sub-concepts of climate justice. They relate to both the processes through which decisions about how to address climate change are made (i.e. procedural justice), and the ways in which the costs of mitigation and adaptation are distributed (in other words, distributive justice).

The reason climate resilience and justice would be contemplated is because of the catastrophic effects of climate change. Thus, climate change results in great environmental impact beyond temperature increases, including sea level rise, melting glaciers and reduced snow cover, extreme weather events, erratic precipitation, droughts and flooding. ${ }^{12}$ The atmosphere is under undue pressure because of emissions of catastrophic substances to the air.

Governance provides us with a broad term for understanding the institutions working across the state, market and civil society. The law is there to ensure justice. Law and governance improvements can be part of the solution - or can be obstacles to progress - in addressing climate change. Modern state citizens have acquired new

9 United Nations on Sustainable Development Goals (n 7).

10 As above.

11 Wikipedia 'Climate resilience' https://en.wikipedia.org/wiki/Climate_resilience accessed (17 September 2018).

12 Centre for International Sustainable Development Law 'Law, governance and climate change' https://www.cigionline.org/sites/default/files/workshop_lima_ peru_2014_web_1.pdf (accessed 12 September 2018). 
rights, which are as inalienable as those rights which nature endows on them. Increasingly important in some countries is the right to a decent and healthy environment. ${ }^{13}$ A number of existing human rights rely on a safe climate for their complete realisation. These include many civil, political, economic, social and cultural rights. For example, the rights to life, health, adequate standard of living, property, self-determination and just and favourable conditions of work, may all rely on conditions of a safe climate. ${ }^{14}$ However, climate change must go hand in hand with efforts to integrate disaster risk measures into national strategies. It is still possible, with the political will and a wide array of technological measures, to limit the increase in global mean temperature to $2^{\circ} \mathrm{C}$ above pre-industrial levels. This requires urgent collective action. ${ }^{15}$ And, if efforts are not geared towards sufficient climate resilience and advancement in climate justice, the atmosphere together with the society, are likely to face undue impact as injustice anywhere is a threat to justice everywhere. It is essential that civil society groups and other institutions involved in climate adaptation activities have a strong and locally driven understanding of the vulnerability of the poorest and most at-risk communities.

Poor governance and weak institutions are often cited as the main drivers of vulnerability, and lack of local participation and investment in community-based climate adaptation strategies are significant barriers to a community's adaptive capacity. ${ }^{16}$ Thus, it is important to increase awareness, beckon and even advise the government, civil societies, legal professionals and even the private sector, to develop adaptation solutions in line with the scale and scope of climate change. Therefore, it means that the burning issue of climate resilience and climate justice is for all to be involved in ensuring a peaceful and calmer world.

\section{Advancing climate resilience and climate justice}

The question of who suffers most from climate injustice yields different answers, depending on who one thinks the main referent object of climate justice should be. A state-centric approach to

13 E Okon 'The Constitution and the protection of the environment in Nigeria' in Epiphany Azinge and Adedeji Adekunle (eds) Administration of justice and good governance in Nigeria (2011) 253.

14 C Giorge 'Role of nongovernmental organizations in the climate change negotiations' (1998) 9 Colorado Journal of International Environmental Law and Policy at 115.

15 As above.

16 International Rivers 'Civil society guide to healthy rivers and climate resilience' https://www.internationalrivers.org/sites/default/files/attachedfiles/intlrivers _civilsocietyguide2013.web_.pdf (accessed 27 September 2018). 
climate justice places the historical responsibility for the majority of all GHG emissions, and thus the responsibility for mitigating action, on the world's 'old' industrialised countries while simultaneously emphasising developing countries' right to lift their populations out of poverty, including through energy intensive industrialisation. It also focuses on how States rather than sub-state groups or individuals might be perpetrators of climate injustice.

An inter-generational perspective on climate justice stretches the time horizon by emphasising current generations', and especially States', responsibility to preserve the planet and its resources for future generations who, unlike present generations in both developed and developing countries, have no lobby at all to influence global climate negotiations. Intergenerational equity presupposes State rights and obligations. ${ }^{17}$ Article 3(1) of the United Nations Framework Convention on Climate Change (UNFCCC) recognises that climate change is fundamentally an intergenerational problem. ${ }^{18}$ It states that: parties should protect the climate system for the benefit of present and future generations of humankind, on the basis of equity and in accordance with their common but differentiated responsibilities. This incorporates the principles of intergenerational and intragenerational responsibility, which clearly addresses the linkage between equity and the "common but differentiated responsibilities' principle. It specifies that the parties should protect the climate system for the benefit of present and future generations of mankind, on the basis of equity and in accordance with their common but differentiated responsibilities and respective capabilities. The relationship between intergenerational and intragenerational equity can be illustrated in two ways. First, it can be described as a conditioning relationship, in which the fulfillment of intragenerational equity is a necessary condition for achieving intergenerational equity. Second, it inherently implies a conflicting relationship, which entails competition for limited resources i.e., whether limited resources should be used to satisfy the urgent needs today or for the long-term protection of future generations.

17 E Brown Weiss 'Climate change, international equity and international law' 9 Vermont Journal of Environmental Law 615 at 616. See also C Batruch 'Hot air' as precedent for developing countries? equity considerations' $(1998 / 1999) 17(1)$ UCLA Journal of Environmental Law and Policy at 45.

18 United Nations Framework Convention on Climate Change 29 May 1992, entered into force: 21 March 1994 https://unfccc.int/resource/docs/convkp/conveng.pdf (accessed on 26 July 2018). See also Principle 3 of the Rio Declaration states that: 'The right to development must be fulfilled so as to equitably meet developmental and environmental needs of present and future generations' 874 entered into force: 14 June 1992) http://www.unesco.org/education/pdf/ RIO_E.PDF (accessed on 27 July 2018); the Stockholm Declaration of the United Nations Conference on the Human Environment proclaims that 'man ... bears a solemn responsibility to protect and improve the environment for present and future generations' (1972). 
A social justice perspective emphasises the responsibility of affluent people, again in both developed and developing countries, towards those who are most vulnerable and least capable of adapting to the adverse impacts of climate change: the world's poor and marginalised. The world's oil producing states have claimed that a transition to renewable energies and a 'green' world economy is unfair to their citizens whose livelihoods depend on oil revenues thus, they have demanded they be compensated for their losses. This, too, is part of the climate justice discourse. It must be stated that intergenerational equity is a form of social justice.

It should be obvious that climate justice is an inherently contested concept. Justice can be used to validate completely opposing strategies and sometimes, to simply defend vested interests or rights. Therefore the challenge for an ethical debate is to relate justice not only to single aspects but to view it from an overall, comprehensive perspective. The concept of justice should be universal, so that it is comprehensible and generally acceptable to all parties, regardless of whether they live in industrial or developing countries.

Despite this, there is no doubt, the government, legal community and civil society groups have the finance and human resources to help mitigate the effects of climate change and ensure climate justice for sustainable development. ${ }^{19}$ Thus, they have huge roles to play in ensuring the world is a better place for everyone. There have been identified ways to advance and build resilience to the climate. The first is to reduce exposure; in the sense that there is a fundamental difference between climatic and non-climatic shocks; because most of the shocks on-farm can be reduced at the source, or limited in their extension, contrary to climatic shocks. ${ }^{20}$ The second is to reduce the sensitivity of systems to shocks. Sensitivity to drought can, for

19 Sustainable development requires managing many threats and risks, including climate change. Because climate change is a growing threat to development, sustainability will be more difficult to achieve for many locations, systems, and populations unless development pathways are pursued that are resilient to effects of climate change. However, a number of studies recognise that not every possible response to climate change is consistent with sustainable development, as some strategies and actions may have negative impacts on the well-being of others and of future generations. See F Denton \& T Wilbanks 'Climate-resilient pathways: adaptation, mitigation, and sustainable development' available at https://www.ipcc.ch/pdf/assessmentreport/ar5/wg2/WGIIAR5-Chap20_FINAL. pdf (accessed 18 September, 2018).

20 Here, the best example is probably the eradication of rinderpest, which has totally suppressed a major risk for livestock and those depending on it. The use of shocks is in consonance with the author's definition of resilience as: resilience can be described as the capacity of systems, communities, households or individuals to prevent, mitigate or cope with risk, and recover from shocks. At first approximation, resilience is the contrary of vulnerability, but importantly it adds a time dimension to the concept: a system is resilient when it is less vulnerable to shocks across time, and can recover from them. See V Gitz \& A Meybeck, 'Risks, vulnerabilities and resilience in a context of climate change' available at http://www.fao.org/3/ai3084e/i3084e03.pdf (accessed 17 September, 2018). 
instance, be reduced by using drought-resistant varieties or keeping stocks of hay and to increase adaptive capacity. This includes considering the modifications of a system, taking into account all the potential shocks and changes altogether (to take into account compensating, cumulative or exacerbating effects). ${ }^{21}$

Those particularly susceptible to the adverse effects of climate change are the world's poor, 'low-lying and other small island countries; countries with low-lying coastal, arid and semi-arid areas or areas liable to floods, drought and desertification, and developing countries with fragile mountainous ecosystems. ${ }^{22}$ Climate resilient pathways include strategies, choices, and actions that reduce climate change and its impact. They also include actions to ensure that effective risk management and adaptation can be implemented and sustained. ${ }^{23}$

Although insurance is an effective risk transfer instrument, it is far too seldom used in developing nations. Schemes can offer victims compensation in the case of loss from climate change, and to some extent, climate injustice. This is particularly important for the poorest and most vulnerable countries and people, because extreme weather events such as hurricanes or droughts can threaten their very existence. ${ }^{24}$

In addition, sustainable management, preservation, conservation and utilisation of natural resources culminates into environmental protection to advance climate resilience. The UN Human Rights Council has included climate change and human rights on its agenda, and has issued several resolutions in which they acknowledge that climate change is a threat to human rights. ${ }^{25}$

The courts, legal practitioners, civil societies, the government can effectively press for climate actions, thereby enhancing transparency, ensuring accountability of the perpetrators of climate injustice, and integrating human rights into climate actions.

21 United Nations on Sustainable Development Goals (n 7).

22 As above.

23 F Denton \& T Wilbanks 'Climate-resilient pathways: adaptation, mitigation, and sustainable development' available at https://www.ipcc.ch/pdf/assessment report/ar5/wg2/WGIIAR5Chap20_FINAL.pdf (accessed 18 September, 2018).

24 'Climate-related loss and damage: Finding a just solution to the politica challenges' available at https://www.brotfuerdiewelt.de/fileadmin/mediapool/ 2_Downloads/Fachinformationen/Profil/Profil19_E_LossAndDamage.pdf (accessed 19 September, 2018).

25 Human Rights Council Resolutions 7/23 (2008); 10/4 (2009); 18/22 (2011). 


\subsection{Environmental ethics and climate change: Between anthropocentrism and ecocentrism}

Before analysing the different roles of the government, civil society and the legal community in advancing climate resilience and justice, it is important that we understand the underlying theories that guide environmental actions globally. This will help in understanding the effect of certain environmental actions which cause climate change. This is called Environmental Ethics.

Environmental ethics is defined as the moral relationship between humans and the natural environment, including nonhuman individuals that populate/constitute it. ${ }^{26}$ Ecocentrism and anthropocentrism are recognised as one of the common ecological moral dilemmas. ${ }^{27}$ Anthropocentrism, in its original connotation in environmental ethics, is the belief that value is human-centred and that all other beings are means to human ends. ${ }^{28}$ The anthropocentric ethic holds that only human beings have moral values and that the ecosystem represents a mere stock of natural resources for satisfying human needs. ${ }^{29}$ It takes a human-centred, or anthropocentric, view of our relationship with nature to emphasise the value of securing the resources needed for further development. Many have argued that anthropocentrism is inevitable and even benign for the aim of environmental protection. ${ }^{30}$ Whereas others argued that anthropocentrism is inadequate for biodiversity conservation. ${ }^{31}$

Ecocentrisim, on the other hand, takes an environment-centred, or ecocentric, view of our relationship to nature to emphasise the value of conserving her integrity and beauty. Environmentally concerned authors have argued that anthropocentrism is ethically wrong and at the root of ecological crises. ${ }^{32}$ That a more fundamental change in the economy, technology, values and attitudes is required

26 R Sandler 'Environmental ethics, overview' 2 Encyclopedia of Applied Ethics (2012) at 105.

27 United Nations Global status of biological diversity [E/CN.17/2001/PC/18] (2001).

$28 \mathrm{H}$ Kopnina and others 'Anthropocentrism: More than just a misunderstood problem' (2018) 31(1) Journal of Agricultural and Environmental Ethics at 109110.

29 TG Jakobsen 'Thinking like a mountain: encountering nature as an antidote to humankind's hostility towards the earth' (2019) 18(1) Journal of Critical Realism at 46.

30 BG Norton 'Environmental ethics and weak anthropocentrism' (1984) 6(2) Environmental Ethics 131-148; A Weston 'Beyond intrinsic value: Pragmatism in environmental ethics' (1985) 7 Environmental Ethics at 321-339; W Grey 'Anthropocentrism and deep ecology' (1993) 71(4) Australasian Journal of Philosophy 463-475.

31 PJ Cafaro \& RB Primack 'Species extinction is a great moral wrong' (2014) 170 Biological Conservation at 1-2.

32 See H Kopnina and others "The "future of conservation" debate: Defending ecocentrism and the nature needs half movement' (2018) 217 Biological Conservation 140-148. 
for the protection of the environment according to them goes without saying. ${ }^{33}$ They propose an ecocentric approach to matters of environmental concerns. The recognition of the intrinsic value of the environment is the focus of the ecocentric approach to environmental protection. ${ }^{34}$ This, because there are deficiencies inherent in the anthropocentric perspective. First, the anthropocentric perspective fails to protect the integrity of the biosphere in and of itself. Then, the anthropocentric perspective emphasises human domination over nature and therefore, the interests of nonhuman species are easily ignored or sacrificed. An adequate environmental ethic must not be limited to consideration of individual interests and no successful environmental ethic can be derived from a purely individualistic approach. ${ }^{35}$

Some environmental ethicists argue, however, that critics of anthropocentrism are misguided or even misanthropic. ${ }^{36}$ They state that the term anthropocentrism is often misused as a criticism of humanity as a whole, and that this is counterproductive for environmental protection, and even misanthropic. ${ }^{37}$ They contend: first that criticism of anthropocentrism can be counterproductive and misleading by failing to distinguish between legitimate and illegitimate human interests. ${ }^{38}$ Legitimate concerns include the need to care for other members of one's own species; and illegitimate concerns include species-ism and human chauvinism. ${ }^{39}$ This is when humans give preference to the interests of members of their own species over the interests of members of other species for morally arbitrary reasons. ${ }^{40}$ Thus, it is not anthropocentrism but species-ism and human chauvinism that are 'bad'.

Their second contention is that, humans differ greatly with regard to their environmental impact, and consequently, addressing human inequalities should be a precondition for environmental protection. ${ }^{41}$ That is, it is unhelpful to criticise humanity in general for practices carried out by a limited number of people, when many others may in fact oppose them. ${ }^{42}$ This is because indeed, many indigenous societies

T Hayward Ecological Thought: An Introduction (1995) at 56.

T Hayward 'Anthropocentrism: A misunderstood problem' (1997) 6(1) Environmental Values 2.

Norton (n 30) 135.

See D Kidner 'Why 'anthropocentrism' is not anthropocentric' (2014) 38(1) Dialectical Anthropology 465-480

Hayward (n 34) at 51.

As above.

Hayward (n 34) 51 \& 59.

Hayward (n 34) 52.

LE Sponsel 'Human impact on biodiversity: Overview' in SA Levin (ed) Encyclopedia of biodiversity (Vol 4) (2014) at 58-59. See also MA Andrich, $\mathrm{J}$ Imberger \& ER Oxburgh 'Raising utility and lowering risk through adaptive sustainability: Society and wealth inequity in Western Australia' (2010) 3(3) Journal of Sustainable Development at 14-35.

Hayward (n 34) 58. 
were not anthropocentric, but industrial Western society has become so. ${ }^{43}$ Furthermore, not all humans benefit from the exploitative activities of some humans. ${ }^{44}$ When the exclusive benefits of exploitation are unacknowledged, the 'anti-anthropocentrists are left vulnerable to ideological rejoinders to the effect that challenging those activities is merely misanthropic'. ${ }^{4}$ Indeed, some scholars have accused environmentalists of putting the blame for biodiversity loss on all humanity, rather than over-exploitive elites. ${ }^{46}$ Given the many documented social ills of inequality, it is often assumed that inequality is an important factor to consider when predicting biodiversity loss. 47

Third, since ecosystems constitute the 'life-support system' for humans, anthropocentrism can and should be a powerful motivation for environmental protection. ${ }^{48}$ That is, human and environmental needs coincide because maintaining the environment for human material benefit is the strongest motivation for nature protection. ${ }^{49}$ Anthropocentric motivation is favoured as the best argument for maintaining the ecological systems on which we depend, ultimately converging into the same practical outcomes as ecocentric positions. ${ }^{50}$ Illustrative of this position is the statement of the World Charter for Nature of the United Nations General Assembly (UNGA), which calls for non-wasteful use of natural resources and observes that humanity benefits from healthy ecological processes and biological diversity. ${ }^{51}$ This is in line with the anthropocentric ambition to guarantee environmental protection in order to benefit humanity as a whole.

43 Sponsel (n 41) 137.

44 Hayward (n 34) 59.

45 As above.

46 M Chapin 'A challenge to conservationists' World Watch (2004) 17 at 21. See also $\mathrm{G}$ Holmes 'Exploring the relationship between local support and the success of protected areas' (2013) 11 Conservation and Society at 72-82; R Fletcher \& B Buscher 'Why EO Wilson is wrong about how to save the earth' (2016) available at https://aeon.co/opinions/why-e-o-wilson-is-wrong-about-how-to-save-theearth (accessed 20 September 2018).

47 TG Holland, GD Peterson, \& A Gonzalez 'A cross-national analysis of how economic inequality predicts biodiversity loss' (2009) 23(5) Conservation Biology at 1304-1313. See also MA Andrich, J Imberger, \& ER Oxburgh 'Raising utility and lowering risk through adaptive sustainability: Society and wealth inequity in Western Australia' (2010) 3(3) Journal of Sustainable Development at 14-35; J Haupt \& C Lawrence 'Unexpected connections: Income inequality and environmental degradation' (2012) Shaping Tomorrow's World available at http:/ /www.shapingtomorrowsworld.org/hauptInequality.html (accessed 23 September 2018); J Elliott An introduction to sustainable development (2013).

48 Hayward (n 34) 60.

49 Norton (n 30) 138.

50 As above.

51 United Nations General Assembly World Charter for Nature UN Doc. A/RES/37/7, 28 October 1982, available at: http://www.un.org/documents/ga/res/37/a37r 007.htm. 
Fourth, that human self-love is not only natural but is helpful as a starting point for loving others, including nonhumans. ${ }^{52}$ Care for others starts with love for oneself. It logically follows from this, theoretically at least, that humanity can be at peace with itself, love itself more, and consequentially have a positive effect on other species. As Hayward states: 'positive concern for human well-being need not automatically preclude a concern for the well-being of nonhumans, and may even serve to promote it'. ${ }^{53}$

However, these arguments in favour of anthropocentrism can be countered in several ways. First, anthropocentric theorists provide fragmented definitions of anthropocentrism by stating that what is objected to under the heading of anthropocentrism in environmental ethics and ecological politics is a concern with human interests to the exclusion, or at the expense, of interests of other species. ${ }^{54}$ This is, in part, true, as reflected in in environmental ethics and animal rights literature. ${ }^{55}$ However, redefining the term anthropocentrism seems to be an attempt to ignore the behaviour in which humans focus on themselves at the risk of the planet. This is because it creates a new meaning of anthropocentrism, namely that of a legitimate concern for human welfare and fails to account for legitimate concerns for nonhuman welfare as it assumes that humans are the arbiters of what is 'legitimate'. Anthropocentric liberals fail to account for many things that matter or provide an ethic sufficient for addressing climate change such as, non-human individuals, other species, ecosystems and the biosphere. A deeper (ecocentric) environmental ethic recognises the welfare of all nonhuman forms. ${ }^{56} \mathrm{~A}$ holistic approach leads to the realisation that both biocentric and ecocentric values make the conservation of the species-variety of the planet (and its genetic diversity) of paramount importance. The lesson in ecology is that in the long run one must use 'systems thinking' to maintain holistic ecosystems. As long as the priority on defending planetary diversity is not lost, such an approach is compatible with 'compassionate conservation', where species and individuals within the species (and their habitats) are protected. ${ }^{57}$

52 Hayward (n 34) 52.

53 As above.

54 As above.

55 A Naess 'The shallow and the deep: Long-range ecology movement' (1973) $16 \mathrm{An}$ Interdisciplinary Journal of Philosophy at 95-100. See also WR Catton \& RE Dunlap 'Environmental sociology: A new paradigm' (1978) 13 American Sociologist at 41-49; E Katz 'Envisioning a de-anthropocentrised world: Critical comments on Anthony Weston's 'the incomplete eco-philosopher' (1999) 14 Ethics, Policy and Environment at 97-101; S Borras 'New transitions from human rights to the environment to the rights of nature' (2016) 5(1) Transnational Environmental Law at 113-143.

56 H Rolston III $A$ new environmental ethics: The next millennium for life on earth (2012) 60.

57 MP Nelson, JT Bruskotter, JA Vucetich, \& $\mathrm{G}$ Chapron 'Emotions and the ethics of consequence in conservation decisions: Lessons from Cecil the lion' (2016) 9(4) Conservation Letters at 304. 
In a similar way, it is important to be clear about the term anthropocentrism, which in its common meaning, is an ideology that is deep-rooted in the value in humanity. Although 'anthropocentrism' might be too imprecise a term to describe conditions that range from the destruction of the wilderness to the abuse of farm animals, we can hardly come up with the alternatively broad and meaningful term. There are of course subcategories of meaning that are markedly anthropocentric. The terms 'industrocentrism', 'human chauvinism' and 'species-ism' are key examples, though they are less known outside academic discourse. Although anthropocentrism has many meanings, at its core it involves the planetary-scale subordination of nonhuman organisms that denies they have value in their own right.

Furthermore, although there are some differences among various anthropocentric positions, there are also some commonalities that do not bode well for nonhuman well-being and biodiversity protection. Principal among these is the lack of ethical consideration for the intrinsic value of nonhuman forms. The commonly-held meaning of the term anthropocentrism is that 'only humans are worthy of ethical considerations' and 'other things are mere means to human ends'. ${ }^{58}$ Yet anthropocentrists change the meaning of the term to mean to care and be compassionate for people. Such erosion of meaning is problematic, because it confuses a formal description of the valuation theory with one legitimate aspect of that theory. Anthropocentrism (applied to humanity as a whole) should be retained as the term that describes a human-centred valuation theory, aspects of which are a powerful explanation for society's current environmental unsustainability and unethical treatment of nonhumans.

Second, anthropocentrists argue that humans differ greatly in their impact on the environment and consequently, addressing human inequalities should be a precondition for environmental protection. They have stated that 'a unified and peaceful body is more likely to be considerate - or at least guided by a far-sighted and ecologically enlightened conception of its self-interest - than one which is riven by internal strife'. ${ }^{59}$ Indeed, not all humans are equal in their impact, as 'there is tremendous diversity in relationships with and impacts on biodiversity'. ${ }^{60}$ This is certainly true, humanity is not harmonious and humans are unequal. But even if they were equal - the evidence of the positive relationship between equality and environmental protection is inconclusive at best. In other words, if addressing human inequalities is a precondition of environmental protection, biodiversity protection will remain out of the scope of ethical consideration for an indefinite period of time. In fact, there is (eds) Principles of conservation biology (2006) 119.

59 Hayward (n 33) 60.

60 Sponsel (n 41) 137. 
consensus among ethicists that the interests of at least some nonhumans are directly morally important. ${ }^{61}$ However, this has not been reflected at all in climate policy discussions, and it has mostly been ignored even within the climate ethics literature. The consensus on the human causes of global warming is almost unanimous within the scientific field, as at least $97 \%$ of actively publishing climate scientists agree that humans are responsible for recent trends in warming and greenhouse gas emissions, which are increasing due to human behaviour. ${ }^{62}$ This is driving up average global temperatures.

Thirdly, anthropocentrists advocate the convergence theory, which is that since ecosystems constitute the 'life-support system' for humans, anthropocentrism can and should be a powerful motivation for environmental protection. ${ }^{63}$ This however supports shallow ecology or protection of nature for human sake and is often associated with strong anthropocentrism or pragmatic environmental ethics. ${ }^{64}$ Pragmatic ethics is based on the assumption that anthropocentric or ecocentric motivations achieve the same ends, for example as in the case of fighting pollution threatening human health. ${ }^{65}$ Anthropocentrism writers state that, 'the best, if not only, reason for preserving eco-systemic relations is precisely that they constitute the 'life-support system' for humans'.66 However, while an anthropocentric motivation can produce environmentally-positive outcomes in situations where both humans and environment are negatively affected, anthropocentrism does not protect nonhumans without utilitarian value, nor safeguard animal welfare. ${ }^{67}$ In fact, the loss of some biodiversity does not affect humanity (at least not yet), as evidenced by mass extinctions. ${ }^{68}$ Moreover, we know the long-term effect of disappearance of keystone species necessary for our survival-however, what keystone species should be saved is in fact unknown and is likely to remain so. ${ }^{69}$ What allows pragmatic ethicists to rehabilitate anthropocentrism, as a basis of an environmental

61 Hayward (n 33).

62 NASA, (2016). Global climate change, evidence. Retrieved from website: http: / / climate.nasa.gov/evidence. See also The Intergovernmental Panel on Climate Change (IPCC) 'Climate Change, the IPCC Scientific Assessment' (1990) available at https://www.ipcc.ch/publications_and_data/publications_ipcc_frst_assess ment_1990_wg1.shtml; IPCC 'Climate Change 2014 - 5th Assessment Report' available at http://www.ipcc.ch/pdf/assessment-report/ar5/syr/SYR_AR5_ FINAL_full.pdf; TM Lenton 'Early warning of climate tipping points' (2011) 1(4) Nature climate change at 204.

63 Weston (n 30) at 329.

64 Naess (n 55) 96.

65 Norton (n 30) at 139. See also Grey (n 30) at 470; Weston (n 30) at 330.

66 Hayward (n 33) at 60.

67 P Singer Animal liberation: A new ethics for our treatment of animals (1977) 200. See also Katz (n 55) at 97-101.

68 E Crist 'I walk in the world to love it' in G Wuerthner, E Crist, \& T Butler (eds) Protecting the wild: Parks and wilderness, the foundation for conservation (2015) 82-95.

$69 \mathrm{H}$ Washington Human dependence on nature: How to help solve the environmental crisis (2013) 78. 
ethic, is their own rejection of the intrinsic value of nature. ${ }^{70}$ By rejecting this intrinsic value, environmental protection is enacted only to the extent needed for human well-being, and a human environmental right subjugates all other needs, interests and values of nature to those of humanity. ${ }^{71}$ Thus, non-anthropocentrism/ ecocentrism is necessary to counter the accelerating threats to environmental elements that do not directly contribute to human welfare. $^{72}$ Anthropocentric motivation is not enough as I hereby illustrate. For example, the World Charter for Nature of the United Nations General Assembly (1982) calls for non-wasteful use of natural resources and observes that humanity benefits from healthy ecological processes and biological diversity. However, this is essentially still an anthropocentric position that sees nature as a resource, where protection extends only to the 'critical natural capital' needed for society - not the rest of nature. ${ }^{73}$ This argument, in fact, is at the root of the concept of ecosystem services, which has now become a dominant paradigm in ecology and conservation literature, and a driving force for governmental and NGO conservation. ${ }^{74}$ The ecosystem services approach however remains anthropocentric, as it focuses on only benefits for people. ${ }^{75}$

The World Charter for Nature of the Untied Nations General Assembly (1982) also states that every form of life warrants respect 'regardless of its worth to man', and as a result, such respect requires us to be 'guided by a moral code of action'. ${ }^{66}$ This moral code of action is not likely to be instructed by the same thinking that produced anthropocentrism as a dominant ideology in the first place. To recall the famous quote by Albert Einstein: 'we cannot solve our problems with the same thinking we used when we created them'. Anthropocentrism does not allow for the possibility of radical change similar to that which ended slavery, and led to rights for women and

70 Katz ( $n$ 56) 99. See also F Mathews 'From biodiversity-based conservation to an ethic of bio-proportionality' (2016) 200 Biological Conservation at 140-148; RF Noss 'The wildlands project land conservation strategy' (1992) 1 Wild Earth at 9-25.

71 L Bisgould 'Power and irony: One tortured cat and many twisted angles to our moral schizophrenia about animals' (2008) 8 Animal subjects: An ethical reader in a posthuman world at 259. See also Borras (n 56) 113-143.

72 F Quinn, J Castera \& P Clement 'Teachers conceptions of the environment: Anthropocentrism, non-anthropocentrism, anthropomorphism and the place of nature' (2016) 22(6) Environmental Education Research at 893-917.

73 P Ekins and others 'A framework for the practical application of the concepts of critical natural capital and strong sustainability' (2003) 44(2) Ecological Economics at 170.

74 Millennium Ecosystem Assessment 'Ecosystems and human well-being: Biodiversity Synthesis' (2005) available at http://www.millennium assessment. org/en/index.html (accessed 18 September 2018).

75 Norton (n 30) at 141-148. See also $H$ Washington Demystifying sustainability: Towards real solutions (2015).

$76 \mathrm{~K}$ Sykes 'Globalization and the animal turn: How international trade law contributes to global norms of animal protection' (2016) 5 Transnational Environmental Law at 55-79. 
ethnic minorities. While the most promising hope for maintaining significant biodiversity under our prevailing value system has been said to be ecologically-enlightened self-interest, it holds no ground if there are risks, and also when exclusive self-interest promises a 'bigger pay off' ${ }^{77}$ As Washington argues, if instead we were to shift to ecocentric values, nature's survival would be ensured even more effectively, along with the ecosystem services humanity depends on. 78

Fourth, anthropocentrists have argued that human self-love is not only natural but helpful as a starting point for loving others, including nonhumans. However, 'self-love' alone is an inadequate basis for environmental concern and action. In fact, we should be cautious to assume that self-love can be considered a precondition of loving others as sometimes in consumer-oriented and often narcissistic societies, self-love often happens to be the goal in and of itself. ${ }^{79}$ Besides, even if ideally humanity can be at peace with itself and be harmonious, this does not mean that it will be collectively biophilic some people will be, some not. ${ }^{80}$ While some cultures respect (holy) cows or worship trees, other communities can be cruel to animals and indifferent to these worldly environmental concerns. ${ }^{81}$ Learning to 'love' or respect one's own tribe does not mean loving animals (or sacred forests and places). Even though some individuals might 'love' animals, there is an increasing proportional difference between the number of people on this earth and the number of nonhumans outside of food and medical industries. 'Self-love' cannot address how the food and medical industries have evolved to serve us at the expense of billions of other species without the protection of law.

In all, anthropocentrism is clearly a significant driver of ecocide, climate change and the environmental crisis, for society has been madly pursuing project 'human planet' without considering that humanity is (in the end) fully dependent on nature. Anthropocentrism cannot lead us to a sustainable future. Ecocentrism, in contrast, accepts that we are part of nature, and have a responsibility to respect the web of life and heal the damage caused by the ideological dominance of anthropocentrism.

77 W Rees 'Toward sustainability with justice: Are human nature and history on side?' in C Soskolne (ed), Sustaining life on earth: Environmental and human health through global governance (2008) 89.

78 Washington (n 69) at 63.

79 D Carnegie How to stop worrying and start living (2004) at 73.

$80 \mathrm{H}$ Kopnina 'Revisiting the Lorax complex: Deep ecology and biophilia in crosscultural perspective' (2015) 43(4) Environmental Sociology at 320. See also B Taylor Dark green religion: Nature spirituality and the planetary future (2010)

81 Taylor (n 80) at 66. See also B Taylor 'It's not all about us: Reflections on the state of American environmental history' (2013) 100(1) Journal of American History at 140-144; B Taylor and others 'The greening of religion hypothesis (part two): Assessing the data from Lynn White, Jr., to Pope Francis' (2016) 10(3) Journal for the Study of Religion, Nature \& Culture 306-378; Sponsel (n 41) 137. 


\subsection{Role of Government}

Most times, suits on climate violation are against the government. This is against the backdrop that there is an obvious duty on the State to protect its people. ${ }^{82}$ The government can effectively make policies for adequate resilience and combat injustice. The government can integrate climate change measures into national policies and strategies; plan and promote mechanisms for raising capacity for effective climate change-related planning and management, including focusing on women, youth and marginalised communities; and strengthen resilience and adaptive capacity to climate-related hazards and natural disasters in all countries. The government can build on existing development and human rights agreements, set up actions to slow climate change, back investment approaches to climate change in order to facilitate climate resilience and environmental justice. Administrative policies should be taken to cover protective and preventive measures so as to reduce potential harm in case of natural disasters and catastrophic accidents. Also, in view of the security interest of its citizens, a high level of meticulousness should be required of the state in matters of the environment which affect the climate. ${ }^{83}$

The government has to help in improving our knowledge. Easy access to information about climate change and technical adaptation measures should be facilitated by the government. Without government intervention, too little information would be generated. Moreover, financing basic research in this area is one of the fundamental tasks for a central government. ${ }^{84}$

Also, the government has to provide the regulatory framework for insurance markets. The economic consequences of natural disasters can be cushioned through insurance markets. However, the incentives to buy insurance are often insufficient for several reasons. If the government wants to avoid being pressured for disaster relief, it has to make disaster insurance mandatory. Furthermore, in order to induce citizens to the appropriate amount of self-protection,

82 UN General Assembly Resolution 53/144 (1998), 'Declaration on the Right and Responsibility of Individuals, Groups and Organs of Society to Promote and Protect Universally Recognised Human Rights and Fundamental Freedoms'. See also Social and Economic Rights Action Centre (SERAC) and Another v Nigeria (2001) AHRLR 60 (ACHPR 2001) paras 44-47; IHRDA and Open Society Justice Initiative (OSJI) (on behalf of children of Nubian descent in Kenya) $v$ Kenya [Communication 2/09 (2011)] para 58.

83 KJ de Graaf and JH Jans, 'The Urgenda Decision: Netherlands liable for role in causing dangerous global climate change' (2015) 27 Journal of Environmental Law at 522.

84 Kai Konrad and Marcel Thum, 'What is the role of governments in climate change adaptation?’ available at https://blog.oup.com/2014/07/governmentadaptationclimate-change/ (accessed 20 September, 2018). 
insurance premiums have to be differentiated according to local disaster risks. 85

Particularly affecting climate justice, and resilience, the following are policies, strategies and legal actions that the government can act on;

\subsubsection{Looking beyond the State: A cosmopolitan perspective on climate justice}

There is the need to find a 'fair' burden-sharing formula. In doing this, the cosmopolitan perspective is suggested. It shows that the real divide is not only between developed and developing states, but also between affluent and poor people. By taking into account not only international but also intra-national equity considerations, it becomes possible to move beyond the simplistic developeddeveloping country dichotomy and to reassess justice among states in the context of the practical realities of climate change. In line with the cosmopolitan perspective, private affluence is thought to be an underlying cause of environmental destruction and a source of financing for public investments in technologies that are necessary to tackle climate change effectively. Summarily, in order to get robust mitigation efforts off the ground, it is essential that the high-carbon lifestyles of the global middle class are regulated and taxed, as well as those of the most affluent people. ${ }^{86}$ Regulating or/taxing high carbon lifestyles must be part of robust mitigation efforts, unless there are very significant and rapid technological breakthroughs. The global costs of adaptation to climate change should be shared, not between states but between the world's wealthy (i.e. those capable of contributing) and the poor (i.e. those most heavily affected but least able to contribute). According to this logic, while the state has an important role as an 'intermediary', funds would essentially flow from the capable to the vulnerable across borders. A cosmopolitan perspective has the potential to offer fairer benefit and burden sharing.

\subsubsection{Legal obligations to combat climate change}

Furthermore, on climate justice, honing in at the state level can nonetheless enhance climate justice by urging states to fulfil their legal obligations with regard to curtailing climate change emissions. There are foundations in existing law that are applicable to climate policy, as highlighted by the Oslo Principles. ${ }^{87}$ According to the

85 As above.

86 PG Harris, A Chow, and R Karlsson, 'China and climate justice: Moving beyond statism', International environmental agreements (2013) 13 \& 301. 
working group, there are many legal methods to force a country to reduce greenhouse gas emissions. Judges may, on the basis of international law, human rights and liability judge what a state must do to prevent the harmful effects of climate change. The centrepiece of the Oslo Principles is the Precautionary Principle, which requires that:

(a) GHG emissions be reduced to the extent and at a pace necessary to protect against the threats of climate change that can still be avoided; and

(b) The level of reductions of GHG emissions required to achieve this, should be based on any credible and realistic worst-case scenario accepted by a substantial number of eminent climate change experts. ${ }^{88}$

The measures required by the Precautionary Principle should be adopted without regard to the cost, unless that cost is completely disproportionate to the reduction in emissions that will be brought about by expending it. By defining the scope of legal obligations relevant to climate change, the Oslo Principles may provide some opinio juris that help judges decide whether governments are complying with their legal obligations to address climate change. The Oslo Principles can be seen both as an awareness raising instrument and as a guide for judges to urge compliance by the state with their existing legal obligations, which can be invoked by civil society to hold their governments accountable when they are not doing enough to mitigate climate change. This approach enhances democratisation through active citizen participation and the claim for transparency and accountability. Thus, a positive side-effect of such responses to climate change is the creation of new ways of governance seeking justice based on good governance principles.

\subsubsection{Climate change as a form of ecocide and a crime against peace}

In addition, due to the irreversible global (environmental) changes that climate change is causing, with its impact extending to future generations, (future) peaceful enjoyment of the damaged environment becomes substantially diminished. Climate change could be considered a form of ecocide occurring on a global scale, with ecocide also recognised as a crime against peace in international and

87 The Oslo Principles on Global Climate Change Obligations (2015). The Oslo Principles were adopted on March 1, 2015, by a group of experts in international, environmental, tort, and human rights law. The working group included thirteen lawyers and scientists from nine countries, including judges of the Supreme Court of Brazil, the Netherlands, India, Australia and the European Court of Human Rights. The Oslo Principles both define the scope of states' legal obligations to protect the environment and outline a means of meeting these obligations. http: / /globaljustice.macmillan.yale.edu/sites/default/files/files/OsloPrinciples.pdf. Principle 1 of the Oslo Principles on Global Climate Change Obligations (2015). 
domestic law. ${ }^{89}$ Today, there is no international law against criminal mass damage and destruction of ecosystems and animals, especially during peacetime. Hence, the principle nulla poena sine lege will almost always apply and hence, to date no single party, internationally, has been convicted of the environmental war crime. ${ }^{90}$ To this end, climate justice can also be extended to the realm of retributive justice. Ecocide describes the significant damage to or destruction of an ecosystem to such an extent that peaceful enjoyment of a part of that environment will be substantially diminished. A growing body of scientific evidence suggests that the earth has reached a 'tipping point'91 and we are approaching 'planetary boundaries'. ${ }^{22}$ A range of immediate and effective mechanisms is needed to safeguard the rights of future generations. However, the rights of nature itself against ecocide also need to be viciously guarded. One step forward could be the creation of the crime of ecocide as a fifth crime against peace.

A research paper by the Human Rights Consortium at the School of Advanced Studies, University of London, has shown that the UN has discussed such a crime for decades, especially throughout the 1970s - 1990s. ${ }^{93}$ The term became known after World War II, in particular, the Vietnam War. ${ }^{94}$ Even though ecocide was eventually shelved last minute in 1996, several countries implemented it in their national legislation, such as Vietnam, the Russian Federation, and other former Soviet countries. ${ }^{95}$ While awaiting international recognition, these issues are being played out in domestic claims. Several states have started to recognise the rights of nature, ecosystems and animals and there has been an increasing recognition of the intersection between human rights and environmental degradation. ${ }^{96}$ In 2010, Bolivia adopted the Law of the Rights of Mother Earth, while Ecuador dedicated an entire chapter of its 2008 constitution to the

89 A Greene 'The campaign to make ecocide an international crime: Quixotic quest or moral imperative?' (2019) 30(3) Fordham Environmental Law Review at 1-2.

90 This means there is no penalty without law.

91 University of California - Berkley, 'Evidence of impending tipping point for earth', Science Daily, (June 2012), available at: http://www.sciencedaily.com/ releases/2012/06/120606132308.htm (accessed 18 September 2018).

92 Stockholm Resilience Centre, 'Planetary boundaries: Guiding human development on a changing planet', (January 2015). Available at: http://science.science mag.org/content/early/2015/01/14/science.1259855 (accessed 18 September 2018).

93 A Gauger and others, Ecocide is the missing 5th crime against peace, Human Rights Consortium, School of Advanced Study, University of London, (2012).

94 RA Falk, Environmental warfare and ecocide - facts, appraisal and proposals, 4Security Dialogue, Princeton University (1973) 80-96.

95 Armenia, the Republic of Moldova, Georgia, Belarus, Ukraine, Kazakhstan, Kyrgyzstan, Tajikistan. See also art 358 of the Criminal Code of the Russian Federation; art 342 of the Vietnam Penal Code.

96 From the right to self-determination, right to economic and social development, right to natural resources, right to communicate to the right to food, right to life, health and human dignity. 
Rights of Mother Earth. ${ }^{97}$ Significantly, several court judgements afford protection to the ecosystems and animals. Countries such as Kenya, South Africa, Uganda and Benin have recognised the sanctity of certain natural sites belonging to indigenous communities. Dolphins have recently been recognised to possess 'personhood' in India. ${ }^{98}$ Belize ruled in the 2009 Westerhaven $v$ Belize case that, 'it is really more accurate to describe and refer to the damage to the Barrier Reef as 'injury' because the reef is a living organism'. 99 In 2008, the Criminal Court of Paris convicted, for the first time, a company for environmental damage. ${ }^{100}$ More recently, in July 2015, Guatemala became the first country to establish a court dedicated to adjudicating the crime of ecocide. In its first case, the Environmental Crimes Court ruled against a palm oil corporation, an industry associated with a litany of human rights and environmental abuses in the country. An appellate court upheld the decision. ${ }^{101}$

Hence, this approach can be adopted by other countries in a bid to pursue climate justice for both citizens and the environment. Ecocide aims to underline the urgent necessity to establish respect for future generations, a principle that was referenced already in several declarations. ${ }^{102}$ While recognising climate change as a form of ecocide, establishing a new norm that prohibits ecocide might not prevent damage to the environment, it could nonetheless send a strong message concerning the obligation upon States, corporations and individuals to protect it. Hence, the official inclusion of ecocide prevention as an international norm can help advance climate justice by, at a minimum, signalling to states, corporations and individuals that they have obligations to mitigate climate change and at a maximum, provide a new mechanism for safeguarding rights violated due to a lack of action to address climate change.

97 Bolivia Ley de Derechos de la Madres Tierra (2010) 1-2.

98 Policy on Establishment of Dolphinarium-Regarding, Circular F.NO, 20-1/2010-CZA (M)/2840 Government of India - Ministry of Environment and Forests (2010), available at http://cza.nic.in/ban on dolphanariums.pdf.

99 Attorney-General of Belize v MS Westerhaven Schiffahrts, Claim No 45 of 2009 (4.26.2010) 37 para 89. Available at http://files.harmonywithnatureun.org/ uploads/upload698.pdf.

100 https://www.nytimes.com/2010/03/31/business/energy-environment/31total. html (accessed 18 September 2018).

101 C Parker, 'Justice in Guatemala: Guatemalan Court upholds revolutionary ruling on ecocide', IC Magazine (January 2016), https://intercontinentalcry.org/justicein-guatemala-guatemalan-courtupholds-revolutionary-ruling-on-ecocide/ available at (accessed 18 September 2018).

102 Principle 1 of the United Nations Stockholm Declaration on the Human Environment, adopted in June 1972, UN Doc A/Conf.18/14/Rev 1(1973). See also Principle 3 of the United Nations Rio Declaration on Environment and Development UN Doc. A/CONF.151/26 (vol I); 31 ILM 874 (1992); United Nations Educational, Scientific and Cultural Organisation (UNESCO) 'Declaration on the Responsibilities of the Present Generations Towards Future Generations' 12 November 1997 Specific reference in terms of article or principle?. 


\subsubsection{Multi-level and multi-stakeholder climate governance to advance climate justice}

To be effective, climate governance needs to include the macro level (intergovernmental and international), the meso level (regional, national, and subnational), and the micro level (municipal, local, and community). It also and especially needs to be non-territorial (corporate, industrial, transnational, and transboundary).

Multilevel governance is needed to create the necessary linkages, by means of participation and deliberation as informed by context, in order to incorporate political and public support, and verify and accredit activities on the ground. This in turn entails fine-tuning bottom-up learning processes with top-down policy strategies and visions.

It is clear that a 'one-size-fits-all' approach for mitigation or adaptation is not appropriate for the complexities of climate change. Strategies should stimulate and support pro-active mitigation and adaptation responses, whilst retaining the flexibility and robustness necessary for enabling the development, testing and implementation of measures at the local scale. The complexities inherent in climate change pose a major challenge for strategic policy communities, since integration needs to occur horizontally across different sectors and policy areas, as well as vertical integration across levels. This ultimately will require the consideration of mitigation or adaptation through existing institutional mechanisms, a process commonly known as 'mainstreaming'. In consequence, this means that local authorities have to adapt their spatial planning, housing, farming, water management, public health and business policies to the environmental and climatic changes. Resettlements and reallocation of people is one of the most applicable adaptation policies which communities and governments have to deal with.

\subsubsection{Outlining a rights-based approach to climate change}

Unequivocally, climate change will have a profound effect on the enjoyment of human rights for billions of people. It is already contributing to food shortages, drought and ecosystem degradation across the entire planet. ${ }^{103}$ Reports of the UNFCCC, UNDP, Human Rights Council, as well as of certain scholars, have shown clearly that the detrimental effects of climate change fall particularly heavily upon more vulnerable sectors of society owing to geography, poverty,

103 Oxfam Entering uncharted waters: El Nino and the threat to food security (2015) 3-4. Available at https://www-cdn.oxfam.org/s3fs-public/file_attach ments/mbel-nino-uncharted-waters_1.pdf. 
cultural and ethnic backgrounds, gender, age or disability. ${ }^{104}$ Furthermore, some regions are hit harder than others.

The concept of 'climate justice' is a perspective that recommends the alignment of climate change prevention, mitigation and adaptation strategies with sustainable development policies that incorporate a human rights-based approach. Essentially, the human rights-based approach implies that challenges and solutions must take full account of; the human rights of individuals and groups affected by climate change, the measures to reduce climate change, and the appropriate adaptation strategies. It aims to ensure that human rights are accorded prime consideration among the wide array of social, political, economic, and security priorities that face Governments and the international community. ${ }^{105}$ In view of this, conservation policies should not be enacted in a way that restricts access to everyone's right to clean and affordable food and water. More broadly, all climate change related international agenda setting and national policy action should ensure the maximum promotion and protection of the human rights of all on a non-discriminatory basis. In this sense, it is essential to identify clearly which and whose human rights are affected, when, where and how. It is crucial to determine the corresponding legal obligations incumbent upon governments, corporations and other key entities to respect such rights when it comes to climate justice issues, as this is the element which lies at the heart of the human rights-based approach. ${ }^{106}$

This implies that policy setting and implementation at all levels should be guided by the basic minimum human rights standards. These are set out in the Universal Declaration of Human Rights (UDHR), as well as by the main multilateral UN human rights treaties. ${ }^{107}$ Also, the Vienna Declaration and Programme of Action, the Declaration on the

104 UNFCCC Paris Climate Change Agreement, available at http://newsroom. unfccc.int/unfccc-newsroom/historic-paris-agreement-available-in-all-six-un-lan guages/ (accessed 17 September 2018); UNDP Report, 'UNDP and Climate Change - Zero Carbon, Sustainable Development', (November 2015); UN Human Rights Council Summary report on the outcome of the full-day discussion on specific themes relating to human rights and climate change, held on 6 March 2015 during the 28th session of the Council; Policy Report by Jane McAdam and Marc Limon, 'Human Rights, Climate Change and Cross Border Displacement: the Role of the International Human Rights Community in Contributing to Effective and Just Solutions' (2015).

105 The OHCHR Report on the Relationship between Climate Change and Human Rights, A/HRC/10/61, (January 2009), available at https://documents-ddsny.un.org/doc/UNDOC/GEN/G09/103/44/PDF/G0910344.pdf?OpenElement.

106 UNEP, in cooperation with Columbia Law School, Sabin Center for Climate Change Law, Climate Change and Human Rights, 15 (December 2015) at 11, 13 \& 26, available at https://web.law.columbia.edu/sites/default/files/microsites/cli mate-change/climate_change_and_human_rights.pdf.

107 For example, The International Covenant on Economic, Social and Cultural Rights (ICESCR), the International Covenant on Civil and Political Rights (ICCPR), the Convention on the Rights of the Child (CRC) or the International Labour Organisation (ILO) Convention No. 169 concerning Indigenous and Tribal Peoples. 
Right to Development, the 2030 Agenda for Sustainable Development, the UN Common Understanding of a Human Rights-Based Approach to Development Cooperation, as well as certain other resolutions and laws at both regional and national level, offer considerable guidance on how to develop climate change policy in a fair and equitable manner, in short, to produce 'climate justice'. ${ }^{108}$

The interconnectedness and interdependence among all human rights, the principles of non-discrimination and equality, democratic accountability, rule of law and political inclusiveness of all stakeholders in policy making and on climate change issues, remain basic and uncontroversial standards. Putting these and other related principles into practice, however, poses concrete challenges in terms of actual implementation. ${ }^{109}$ These principles remind policy makers that civil and political rights cannot be accorded priority over the economic, social and cultural rights, or the other way around. Practically speaking, the principles of the rule of law, participation, inclusion and access to information, require that law and policy processes, as well as the adjudication of disputes, be done according to the law rather than in an arbitrary manner. In this context, all affected communities, must be genuinely, thoroughly and diligently consulted on the decisions which are likely to affect them with regard to climate-related issues. It requires that those who are unavoidably disadvantaged from climate policy decisions be adequately compensated for their loss, that the disadvantage itself be minimised and that everyone has recourse to challenge the law and policy in climate related matters, so that injustices can be fairly redressed. ${ }^{110}$

In short, climate justice has to adopt a consistent human rightsbased approach for the following reasons:

- First, the effects of climate change and the measures to prevent, reduce or mitigate these effects, together with climate change adaptation strategies, inevitably affect the human rights of individuals and groups. In order to fully recognize the human rights implications of climate change issues, a human rights-based approach therefore has to be taken. An approach that accurately identifies which and whose human rights are affected and how they are

108 Resolutions such as UN Human Rights Council Resolution 7/23 (2008) that acknowledged the threat of climate change (March 2008). See also UN General Assembly Resolution 64/292 (2010) that explicitly recognised the human right to water and sanitation and acknowledged that clean drinking water and sanitation are essential to the realisation of all human rights (2010).

109 Report by the Food and Agriculture Organization of the United Nations and Earthscan, 'The state of the world's land and water resources for food and agriculture - managing systems at risk', (2011).

110 M Silina European Environmental Bureau \& European ECO Forum, is everything right with public participation in climate related decisions?, Presentation for the Fifth Meeting of the Task Force on Public Participation in Decision-making, Geneva, February 23-24 (2015). 
affected; as well as the kinds of approaches that should be taken to provide redress to those persons;

- Second, climate justice can be achieved only if the human rights guaranteed in all universal human rights standards and norms, of everyone affected in any way by climate change, are fully respected;

- Third, where legal disputes arise in relation to climate change issues, the courts and any other dispute resolution mechanisms, must adjudicate the matter in line with international human rights law.

\subsection{Role of civil society and individuals}

Civil society groups have been empowered to champion courses of climate change in some countries. For instance, the European Union law confers many rights on individuals and non-governmental organisations (NGOs) in order to equip them to act as environmental watchdogs. ${ }^{111}$ Moreover, as a part of global collective action, greater emphasis should be given to the role of diverse coalitions that are already emerging at the community, local, city, corporate and country levels and the vital role they play in mobilising actions. Some of these coalitions are already championing the solutions needed to solve the crisis and their effect can be maximised by supporting them to connect and scale up for greater impact. ${ }^{112}$

Advocacy on behalf of the climate is ultimately advocacy on behalf of the billions of people whose lives depend on a healthy planet. The global climate is interconnected, both environmentally and socially. Fixing an interconnected world demands interconnected movement; anyone who believes that all individuals deserve basic human and civil rights should see the climate crisis as an imminent threat. The issue of climate resilience and climate justice apparently involves all hands to be on deck, if not, the threats climate change portends will persist. In the same vein, social or institutional assets within a determined society are needed. Partnership with other civil society groups and the government could be of immense help to facilitate climate resilience and fight for climate justice. ${ }^{113}$

The role of civil society groups can be further outlined below:

(i) Accelerating Climate Action: Civil society groups should encourage decision-makers to explicitly adopt the precautionary principle

111 A Ryall 'Access to environmental information in Ireland: Implementation challenges' (2011) 23(1) Journal of Environmental Law at 45.

112 As above.

113 For instance, Partnership for the Development of Environmental Law in Africa (PADELIA). Its overall vision is to enhance the capacity of African countries in building capacity for development, implementation and enforcement of environmental laws and to strengthen environmental institutions for sustainable development and poverty reduction. It seeks to assist African governments in building capacities for developing, strengthening, implementing and harmonising their environmental legislation. 
when planning new projects that might have a large environmental or social impact. The precautionary principle is defined as a principle undertaken when an activity raises threats of harm to human health or the environment and precautionary measures are taken even if some cause-and-effect relationships are not fully established scientifically. ${ }^{114}$ Also, civil society groups can develop small-scale integrated river-basin projects that help promote climate resilience by helping vulnerable groups prepare for, withstand and recover from the negative effects of climate change. ${ }^{115}$

(ii) Enhancing Transparency and Accountability: Decision-making processes should follow widely accepted principles of good governance, chiefly: transparency, accountability, timeliness, and responsiveness. Groups can urge the government to recognise that the community groups that are most affected have a legitimate claim for being involved in decision-making processes and ensure that dispute resolution processes are accessible and fair in order to attain climate justice and good governance in society. ${ }^{116}$

(iii) Integrating Human Rights into Climate Actions: Civil society groups can submit parallel reports on human rights and climate change to the appropriate authorities. They can also build coalitions with local groups to document and report human rights issues at the national level and bring them to the attention of international human rights mechanisms. ${ }^{117}$ Furthermore, they can monitor, lobby, and support governments, businesses and other actors in the implementation of climate commitments. Moreover, they can raise awareness of climate change and its human rights impact and build capacity at the state and national level; bring appropriate actions before human rights mechanisms and courts to flesh out State and business obligations related to climate change because sometimes the victims of the climate injustice may not have the opportunity to table their complaints to the appropriate authorities.

(iv) Improved Public Access to Climate Information: Organised civil society groups can, in their capacities, provide adequate information concerning climatic situations. Civil society groups could act as a tunnel between research institutes and the population, leading to a more direct dialogue. Information could as

114 'Climate Resilience' available at https://en.wikipedia.org/wiki/Climate_ resilience (accessed 17 September 2018).

115 As above.

116 As above.

117 'Summary of Recommended Actions on Human Rights and Climate Change from OHCHR Expert Meeting' of 6 - 7 October'. Available at https://www. google.com/ url?sa=t\&rct $=j \notin q=\&$ esrc $=$ s\&source $=$ web\&cd $=1 \&$ ved $=0$ ahUKEWigOfnMP7WAhWDYVA KHUmcAmEQFgglMAA\&url=http\%3A\%2F\%2Fwww.ohchr.org\%2FDocuments\%2Flssues \%2FClimateChange\%2FEM2016\%2FSummaryRecommendations.docx\&usg=AOvVaw1 Fikbp5brRmHJOK84TC95 (accessed 19 September 2018). 
well come through education of the masses about their rights to climate justice. ${ }^{118}$

\subsection{Role of the legal community: Case law discussion}

Courts provide a public forum for persons who are affected by climate change to have their concerns and claims heard and determined. Any person with a justiciable claim is entitled to bring proceedings in a court of competent jurisdiction and have it heard and determined. This accessibility is a hallmark of the judicial branch of government. ${ }^{119}$ Thus, there are a number of cases which the courts have successfully handled with regard to climate change. These are landmark cases that prove that the legal community has a fundamental role to play in ensuring climate resilient measures and climate justice.

In Urgenda Foundation $v$ The Netherlands, the Hague District Court found that the Netherlands must do more to avert the imminent danger posed by climate change in view of its duty of care to protect and improve the living environment. ${ }^{120}$ In addressing the fact that Dutch contribution to global climate emissions is $0.5 \%$, the Court said that any anthropogenic greenhouse gas emission, no matter how minor, contributes to an increase in carbon dioxide levels in the atmosphere and therefore, to hazardous climate change.

In addition, the Court found a sufficient causal link 'can be assumed to exist' between Dutch emissions, global climate change, and the effects. The Court determined the Dutch government must reduce carbon dioxide emissions by a minimum of 25\% (compared to 1990) by 2020 to fulfil its obligation to protect and improve the living environment against the imminent danger caused by climate change. ${ }^{121}$

In Julian v United States, 21 youth plaintiffs and Dr Hansen sued the federal government of the United States for allowing and encouraging increasing carbon emissions over the past 50 years, despite knowing about global climate change. ${ }^{122}$ The plaintiffs claim

118 Art 3(4) of European Union Directive 90/313 on the Freedom of Access to Information on the Environment $(\mathrm{OJ} L 154,56)$ provides that a public authority is to respond to a person requesting information as soon as possible and at the latest within two months and that the reason for a refusal to provide the information requested must be given. See also V Edwards 'European Court of Justice - significant environmental cases 2005' (2006) 18 Journal of Environmental Law at 163.

119 B Preston 'The contribution of the courts in tackling climate change' (2016) 28 Journal of Environmental Law at 11-17.

$120 \mathrm{C} / 09 / 456689 / \mathrm{HA}$ ZA 13-1396 (24 June, 2015) Hague District Court, available at: https://elaw.org/system/files/urgenda_0.pdf (accessed 12 September 2018).

121 Case summary available at https://elaw.org/nl.urgenda.15 (accessed 12 September 2018).

122 Case No 6:15-cv-01517, filed 11/10/2016. 
the federal government violated their constitutional due process and public trust rights and demanded that the government design and implement a plan to slash carbon emissions. The district court of Oregon held that there is a constitutional right to a safe climate for the youth of America and the world.

Gbemre $v$ Shell Petroleum Development Company of Nigeria was an instance where an individual and community in the Niger Delta of Nigeria, filed a suit in the Federal High Court of Nigeria against Shell and other major oil companies to stop gas flaring. ${ }^{123}$ Gas flaring in Nigeria has contributed more greenhouse gas emissions than all other sources in sub-Saharan Africa combined, as well as poisoning local communities. The court held that the gas flaring was a gross violation of constitutionally guaranteed rights to life and dignity. This was the first time that a Nigerian court applied the rights to life and dignity in an environmental case. ${ }^{124}$

Petition to the Inter American Commission on Human Rights Seeking Relief from Violations Resulting from Global Warming Caused by Acts and Omissions of the United States: The Arctic Inuit, filed a petition arguing that the impact of climate change in the Arctic infringes upon the environmental, subsistence, and other human rights of Inuit. ${ }^{125}$ The Inuit sought a ruling from the Commission that the US must adopt mandatory limits on greenhouse gases and '... help the Inuit adapt to unavoidable impacts of climate change.' The Inuit relied on the breach of the following rights set out in the American Declaration of Rights and Duties of Man: the right to life (Art. 1), the right to residence and movement (Art. VIII), the right to inviolability of the home (Art. IX), the right to preservation of health and to wellbeing (Art. XI), the rights to benefits of culture (Art. XIII) and the right to work and to fair remuneration (Art. XIV). The Commission technically dismissed the Petition in December 2006. A hearing was however held in March 2007. No hearing report appears to have been published. ${ }^{126}$

These decisions have inspired environmental lawyers in the same and several other countries to see if they have opportunities in their domestic courts to pursue similar litigation. The legal community should become much more active in the fight against the overwhelming problem of climate change. Though it remains unclear

123 (2005) AHRLR 151 (NgHC 2005).

124 Climate Justice Programme, 'Human rights' available at http://climate justice.org.au/issue/human-rights/ (accessed 20 September 2018).

125 Petition to the Inter American Commission on Human Rights Seeking Relief From Violations Resulting From Global Warming Caused by Acts and Omissions of the United States, December 7, 2005, available at: http://blogs2.law.columbia.edu/ climate-change-litigation/wp-content/uploads/sites/16/non-us-case-documents/ 2005/20051208_na_petition.pdf (accessed 10 October 2019).

126 As above. 
how the courts can enforce its ruling, it should still initiate a change and hopefully the other branches of government will follow suit. ${ }^{127}$

Moreover, because court cases are often costly, cumbersome, technical and time consuming, the legal professionals can effectively use Alternative Dispute Resolution to serve as an essential function in the attainment of justice, especially where loss and damage is involved. Conciliation and mediation have both been known for many years in practically every community as methods of settling disputes by consensus rather than by adjudication.

Creation of environmental dispute resolution mechanisms to facilitate climate justice would be invaluable. The mechanism may include conciliation, mediation and even arbitration. In conciliation, climate infringement disputes may be settled between the disputing parties through consultation and negotiation. Conciliation is considered because it is probably a most speedy, flexible, inexpensive and efficient way of resolving environmental disputes, if the two parties are willing to reach a compromise. However, there is a high moral risk involved in conciliation due to the lack of an external binding force between the parties. ${ }^{128}$

In addition, provision of pro bono services for climate justice could be of great benefit to society. Most victims of climate injustice are farmers, peasants, fishermen, rural dwellers; they may not have the financial wherewithal to undertake legal actions against climate injustice perpetrators such as, multinational companies. Therefore, pro bono services could be a bedrock of advocacy for vulnerable groups and individuals in society by the legal community.

Furthermore, building capacity to undertake legal reforms is apt for both climate resilience and climate justice, although, legal reforms require appropriate institutional, technological, financial and human capacities. Capacity building refers to strengthening skills, competencies and abilities of people, as well as improving technological support to the reform process. These measures are often complementary instruments to legal reform and often attract international financing support. ${ }^{129}$

127 I Quimosing \& E Armas, 'The role of the judiciary in climate change' available at https://law.stanford.edu/2015/10/11/role-judiciary-climatechange/ (accessed 20 September 2018).

128 See generally, Yuhong Zhao, 'Environmental dispute resolution in China' (2004) 16(2) Journal of Environmental Law at 157-192.

129 UN Environmetal Program, 'The role of legal instruments to support green lowemission and climate-resilient development' http://www.undp.org/content/ dam/undp/library/Environment\%20and\%20Energy/Climate\%20Strategies/LECRDS _Legal_Guide.pdf (accessed 12 September 2018). 


\section{Mechanisms for loss and damage}

As a result of a failure to have resilient measures against climate change, loss and damage becomes the consequence. Loss and damage is the term used in climate policy for the worst impacts of climate change - those that go beyond people's ability to cope and adapt. It includes extreme events, like droughts and tropical storms, and slowonset events like sea-level rise, increasing temperatures, glacial retreat causing flooding and eventual drought, and desertification. ${ }^{130}$ Climate Focus Client Brief on the Paris Agreement IV defines loss and damage as:

Sudden and slow-onset events of climate change which cause harm in developed and developing countries alike. Conceptually, loss and damage arises when the adverse effects are not avoided through mitigation and adaptation. In the UNFCCC context, loss and damage involves the development of approaches to address the effects of such events on the most vulnerable developing countries, who are recognised as bearing disproportionate costs from climate change, having both contributed the least to the problem and the least capacity to manage its negative impacts. ${ }^{131}$

The best aspect of climate justice is the enforcement of mechanisms for accessing and proper award of damages and apportioning of loss to deserving parties. Meanwhile, in ensuring that these mechanisms are fully implemented, suggested areas include but are not limited to, enhancing knowledge and understanding of risk management approaches; strengthening dialogue, coordination, coherence and synergies among relevant stakeholders; enhancing action and support on loss and damage, including finance, technology and capacity building, etc. Many climate change researchers and practitioners argue that to best facilitate resilience-building, loss and damage action should aim to result in multiple benefits to nations and communities, such as sustainable development and poverty reduction gains. ${ }^{132}$

The Warsaw International Mechanism for Loss and Damage (WIM) was established at COP-19 (Conference of Parties) in 2013. WIM is the main institution under the UNFCCC to address loss and damage associated with the impacts of climate change, including extreme and

130 K Boom, J Richards \& S Leonard 'Climate justice: The international momentum towards climate litigation' available at https://www.boell.de/sites/default/ files/report-climate-justice-2016.pdf (accessed 18 September 2018) 8.

131 Climate Focus, 'Loss and damage in the Paris Agreement' available at http:// www.climatefocus.com/sites/default/files/20160214\%20Loss\%20and\%20Damage \%20Paris_FIN.pdf (accessed 16 September 2018).

132 A Durand \& SaleemulHuq, 'A Simple Guide to the Warsaw International Mechanism on Loss and Damage' available at http://www.icccad.net/wpcontent/ uploads/2015/09/A-simple-guide-to-the-Warsaw-InternationalMechanism.pdf (accessed 17 September 2018). 
slow onset events, in developing countries that are particularly vulnerable to the adverse impacts of climate change. WIM has three key functions:

(1) enhancing knowledge and understanding loss and damage and how to address it;

(2) strengthening dialogue among relevant stakeholders; and

(3) enhancing action and support on loss and damage, including in the areas of finance, technology and capacity building. ${ }^{133}$

Whether WIM will be enough to meet the needs of vulnerable countries in managing the challenge of loss and damage will be judged over time. WIM is not (yet) meant to be an instrument for delivering much needed additional finance to poor countries and communities. However, it can lay the basis for a meaningful response from the international community. ${ }^{134}$

\subsection{Adequate insurance mechanism}

The provision of an adequate insurance mechanism can alleviate the plight of the victims of climate disasters. Thus, climate-risk insurance has the following potential benefits:

(a) It helps promote guaranteed, timely finance, and provides farmers with financial liquidity in the aftermath of extreme weather events and prevents the farmer from falling into the trap of poverty as a result of losses incurred due to climate impacts.

(b) Agricultural insurance results in stabilising income in the entire agriculture value chain, resulting in improved food security, secured future food production and secured financing options as a result of stable income. Revenues for agricultural businesses (seeds, fertilizers) are also stabilised by sales to farmers and elaborated customer base as a result of subsidised insurance.

(c) It facilitates risk management practices.

(d) It is also transformative in terms of promoting a planned, systematic and well-designed approach to risk rather than ad-hoc crisis response. ${ }^{135}$

Meanwhile, key limitations of insurance include: (1) it does not prevent or reduce the likelihood of direct damage and fatalities from extreme weather events; and (2) it is not always the most appropriate option to manage risks (for example, in terms of cost-effectiveness or affordability). These same limitations are potentially aggravated in a climate change context (i.e. more frequent and intense extreme

133 J Kreienkamp \& L Vanhala 'Climate Change Loss and Damage' available at https: / / www.ucl.ac.uk/global-governance/downloads/policybriefs/policybrief-loss-anddamage (accessed 19 September 2018).

134 Ryall (n 111) at 45.

135 Bond Development and Environment Group (DEG) 'Equitable, Effective and Propoor Climate Risk Insurance Working Paper.' Available at https://www.bond. org.uk/sites/default/files/resourcedocuments/deg_climate_risk_insurance_aug ust_2016.pdf (accessed 18 September 2018). 
events). Climate change also poses additional challenges for insurance, a point that further underscores the vital importance of disaster risk reduction. Two of these issues include: potential uninsurability associated with increasing frequency and magnitude of extreme weather events and unsuitability of traditional insurance for longer-term foreseeable hazards like sea-level rise and desertification. ${ }^{136}$ However, the government, legal community and civil societies should ensure the provision of insurance to climate change prone areas to increase surveillance, because insurance can be seen as an important tool for addressing climate change and disaster risk management, in addition to other prevention and security measures such as, development of a disaster modelling system beyond risk sharing and incorporation of risk management cycle into the government budget planning. When properly designed, the insurance system can be used as a market-based instrument against moral hazards and influencing risk behaviour. It can also positively impact awareness raising and disaster proofing for adaptation actions and financial decisions. ${ }^{137}$

\subsection{Adequate finance for loss and damage}

The government can legislate stiffer and stringent laws to help improve climate justice. For instance, in Nigeria, Paragraph 8.1 of EGASPIN69 provides that 'a spiller shall be liable for the damage from a spill for which he is responsible. ${ }^{138}$ Where more than one spiller is liable, the liability shall be joint and several.'139

Some governments, especially in developing countries, shy away from being signatories to international conventions for example, the Paris Agreement. ${ }^{140}$ Therefore, other international treaties that are aimed at building resilience and encourage fight for climate justice should be opted into by African countries, and they are encouraged to participate actively.

136 Munich Climate Insurance Initiative, 'Adaptation to Climate Change: Linking Disaster Risk Reduction and Insurance' available at http://unfccc.int/resource/ docs/2009/smsn/ngo/163.pdf (accessed 21 September 2018).

137 World Bank Group, 'Insurance against Climate Change', available at http:// www.moew.government.bg/static/media/ups/tiny/file/Climate/Insurance_Again st_Climate_Change.pdf (accessed 21 September 2018).

138 Environmental Guidelines and Standards for the petroleum Industry in Nigeria 200 published by the Department of Petroleum Resources (DPR) para 8.1, 'Liability'.

139 Further, Article 41 of Environmental Protection Law of China provides that 'those who have caused environmental population and damage shall eliminate harm and pay compensation to the units or individuals directly injured by the harm'.

140 The Paris Agreement builds upon the Convention and - for the first time - brings all nations into a common cause to undertake ambitious efforts to combat climate change and adapt to its effects, with enhanced support to assist developing countries to do so. As such, it charts a new course in the global climate effort. The Paris Agreement's central aim is to strengthen the global response to the threat of climate change by keeping a global temperature rise this century well below $2^{\circ} \mathrm{C}$ above pre-industrial levels and to pursue efforts to 
The United Nations Framework Convention on Climate Change (UNFCCC) texts specify a wide range of elements of funding provision for loss and damage. They outline an assortment of approaches for preventing and dealing with loss and damage (including inter alia financial support for development of insurance schemes and risk transfer mechanisms, early warning systems, emergency preparedness measures). It discusses the provision of financial support for parties' efforts to implement their own risk management strategies and for the financial support for international institutions. ${ }^{141}$ The bane has always been the full implementation of the provisions of the Convention. Therefore, Member States are encouraged to give effect to those provisions.

In addition, innovative finance mechanisms could provide a viable way to mobilise predictable funding for loss and damage. The idea of a global carbon tax, a financial transaction tax, an international airline passenger levy or a fossil fuel extraction levy has received particular attention. On a global level, however, these mechanisms remain largely untested so far. Inevitably, they will also raise questions about how finance should be distributed. ${ }^{142}$

\subsection{Addressing climate migration}

Climate change, on its own, does not directly displace people or cause them to move but it produces environmental effects and exacerbates current vulnerabilities that make it difficult for people to survive where they are. ${ }^{143}$ It is expected to make the world hotter, rainfall more intense, and result in more extreme weather events such as droughts, storms and floods. ${ }^{144}$ These changes, in turn, will likely result in further population movements. According to the UN

limit the temperature increase even further to $1.5^{\circ} \mathrm{C}$. Additionally, the agreement aims to strengthen the ability of countries to deal with the impacts of climate change. To reach these ambitious goals, appropriate financial flows, a new technology framework and an enhanced capacity building framework will be put in place, thus supporting action by developing countries and the most vulnerable countries, in line with their own national objectives. The Agreement also provides for enhanced transparency of action and support through a more robust transparency framework. Culled from United Nations Framework Convention on Climate Change, 'Paris Agreement' http://unfccc.int/paris_agree ment/items/9485.php (accessed 12 September 2018).

141 A Durand \& others Financing options for loss and damage: A review and roadmap, available at https://unfccc.int/files/adaptation/groups_committees/loss_and_ damage_executive_committee/application/pdf/browncdlicccadfinancinglossand damagepaperdraft.pdf (accessed 19 September 2018)

142 Ryall (n 111) at 45.

143 United Nations High Commissioner for Refugees (UNHCR) 'Climate change and disaster displacement', available at https: //Www.unhcr.org/climate-change-anddisasters.html (accessed 10 October 2019).

144 International Organisation for Migration (IOM), Migration, Environment and Climate Change: Accessing the Evidence' available at http://publi cations.iom.int/system/files/pdf/migration_and_environment.pdf (accessed 21 September 2018). 
International Strategy for Disaster Reduction (UNISDR) - storms, floods and droughts - have increased threefold over the past 30 years. ${ }^{145}$ Some environmental changes, such as hurricanes and earthquakes, occur with little or no warning and require that people move quickly. Others develop more slowly and may provide time for people to assess their options, leave in an orderly manner and even bring resources with them. However, certain thresholds or 'tipping points' may be reached, where there is little choice left but to move.

The extent to which the environment, including climate change, is the primary driver of migration remains debatable for several reasons. Migration can also affect the environment in terms of additional stress on already degraded lands and competition for scarce resources in both rural and urban settings. ${ }^{146}$

In addressing climate migration, the government and the legal community can formulate policy response and legal framework, respectively. More efforts are needed to identify, test and implement new programmes, policies and frameworks to manage future movements of people linked to environmental and climate change. The capacities of governments to implement existing ones need to be enhanced. Migration can be among several adaptation strategies as exemplified in several National Adaptation Programmes of Action (NAPAs). Countries of destination lack coherent policies to address potential future flows. Measures specifically targeting migration in relation to the environment are ad hoc at best. ${ }^{147}$

Meanwhile, in the event of movement of persons, civil society groups can help provide alternative destinations. Most times, those affected have no other place to go. Hence, the creation of an internally or internationally displaced people's camp can help mitigate the sufferings of the displaced persons.

\section{Conclusion}

Climate change is a world problem. Unfortunately, these problems are exacerbated by reluctant approaches to stimulate resilience. The principle of good governance is essential to the rule of law. In the climate change context, it requires the enactment and enforcement of clear and effective laws that support sustainable developmentdevelopment that meets the needs of the present generation without compromising the ability of future generations to meet their own needs. On the other hand, many victims of climate justice have suffered huge environmental losses and damage without adequate 
compensation from the perpetrators of the injustice. Thus, the role of civil society groups in monitoring the implementation of international treaties, their relevance in the organisation of development projects, and their importance in the representation and education of the society has been acknowledged and valued by both international organisations and national governments. ${ }^{148}$

The role of the international community to advance climate resilience and climate justice cannot be overstated. For instance, WIM created approaches to ensure adequate compensation for climate injustice. In the same vein, the legal community, through a reassurance of justice can effectively harmonise and ensure climate justice, especially as the cases come to court. The legal community, i.e. the courts and the legal professionals, have a higher burden to integrate human rights into climate actions - through the fight for human rights.

Summarily, there are identified challenges to the full actualisation of climate resilience and the fight for climate justice. Some of these challenges include a lack of enforcement of climate laws, reluctance of governments to collect and provide requisite information required to make informed decisions, corruption and inefficiency, undue political interference with the work of regulatory agencies, inconsistent political positions and structures, abject poverty and lack of knowledge, and in the oil producing states, overdependence on oil which has adverse environmental effects. ${ }^{149}$ We need to act decisively to change humanity's relationship with our planet based on the concept of 'common but differentiated responsibility' recognising the need for global action and the differing levels of obligations placed upon industrialised and developing countries. The key to achieving climate resilience and climate justice is for the government, courts, legal professionals, civil organisations and stakeholders to effectively play their roles in making the world a better place.

148 Giorge (n 14) 115.

149 An environmental effect means a natural or artificial disturbance of the physical, chemical, or biological components that make up the environment. See also BA Garner, Black's Law Dictionary, (9th ed) (2009) 614. 